\title{
The effects of intrathecal administration of betamethasone over the dogs' spinal cord and meninges ${ }^{1}$
}

\author{
Efeitos determinados na medula e nas meninges pela administração subaracnóidea de \\ betametasona em cães
}

\author{
Guilherme Antonio Moreira de Barros², Mariângela Esther Alencar Marques ${ }^{3}$, Eliana Marisa Ganem² \\ 1. Research performed at Department of Anesthesiology, School of Medicine of Botucatu, São Paulo State University (UNESP), Brazil. \\ 2. PhD, Assistant Professor, Department of Anesthesiology, Co-responsible Division of Pain Management and Palliative Care Subject, UNESP, Brazil. \\ 3. PhD, Assistant Professor, Department of Pathology, UNESP, Brazil.
}

\begin{abstract}
Purpose: To determinate the potential clinical and histological changes due the injection of betamethasone, when administered into the canine intrathecal space. Methods: Twenty one animals were included in a random and blind manner in the study. After general anesthesia, intrathecal puncture was performed and $1 \mathrm{ml}$ of the random solution was injected. The G1 dogs received $0.9 \%$ saline solution, the G2 dogs received $1.75 \mathrm{mg}$ betamethasone and the G3 dogs received $3.5 \mathrm{mg}$ of betamethasone. The animals were clinically evaluated for 21 days and then sacrificed. The lumbar and sacral portions of the spinal cord were removed for light microscopy histological analyses. Results: No clinical changes were observed in any of the animals included in this study. No histological changes were observed in G1 animals. Inflammatory infiltration was observed in two dogs, one in G2, another in G3. Hemorrhage and necrosis were also seen in the G2 dog which inflammatory infiltration was detected. In other two dogs, one from G2 and another from G3, there was discreet fibrosis and thickness of the arachnoid layer which was focal in one and diffuse in the other. Conclusion: Intrathecal administration of betamethasone caused histological changes in the spinal cord and meninges in some of the dogs involved in this study. Key words: Adrenal Cortex Hormones. Betamethasone. Toxicity. Arachnoiditis. Dogs.
\end{abstract}

\section{RESUMO}

Objetivo: Determinar possíveis alterações clínicas e histológicas determinadas pela administração da betametasona no espaço subaracnóideo de cães. Métodos: Vinte e um cães foram incluídos no estudo de forma aleatória e encoberta. Depois de anestesiados, os cães foram submetidos a punção subaracóidea com injeção de $1 \mathrm{ml}$ da solução sorteada. Os animais receberam solução salina 0,9\% em G1, betametasona na dose de 1,75 mg em G2 e betametasona na dose de 3,5 mg em G3. Todos os animais foram mantidos em observação clínica por 21 dias, sendo posteriormente sacrificados. Porções da medula espinhal e sacral foram removidas para análisehistológica pormicroscopia óptica. Resultados: Não foram detectadas alterações clínicas em quaisquer dos animais incluídos no estudo. Da mesma forma, nenhum animal do G1 apresentou alterações histológicas. Infiltração inflamatória foi observada em dois cães, um do G2 e outro e G3. No cão do G2 onde a infiltração inflamatória foi observada ocorreu, conjuntamente, hemorragia e necrose. Em dois cães, um de G2 e outro de G3, observou-se discreta fibrose e espessamento da aracnóide, sendo focal em um e difusa no outro. Conclusão: A administração subaracnóidea de betametasona determinou alterações histológicas em medula e meninges de alguns dos cães envolvidos no estudo. Descritores: Corticosteróides. Betametasona. Toxicidade. Aracnoidite. Cães. 


\section{Introduction}

Intervertebral disc herniation may allow the contents of the nucleus pulposus to extravasate. This content is rich in phospholipase-A, a potent inflammatory mediator that may be responsible for the pain process in the dorsal pain.1 Corticosteroids have been used epidurally for treating lumbosciatic pain with a relatively secure profile for a long time, ${ }^{2,3,4,5,6,7,8}$ however some controversy does exist. ${ }^{9}$ The corticosteroids use thru intrathecal route has been associated with severe nervous system complications, such as adhesive arachnoiditis (AA). This complication is more likely to happen when depo-corticoids, such as methylprednisolone, are used. ${ }^{10,11,12,13}$ When an epidural block is performed there is calculated risk of $5 \%$ of inadvertent intrathecal puncture, ${ }^{14}$ which makes neural axis use of these medications less secure. The justifications for the injection of corticoids in the epidural route are their maximum antiinflammatory action close to the affected nerve root with lower systemic effects, although there are many reports in literature of the risks of Cushing syndrome and other complications. ${ }^{8,15,16,17}$ AA is a severe and rare complication characterized by bladder and intestinal dysfunction, loss of sensibility, and weakness. The clinical features resemble cauda equina syndrome but the symptoms begin in a slower manner and they may result in paraplegia and death. ${ }^{18,19}$, 20 The histological characteristics are proliferation and fibrosis of the leptomeninges with obliteration of the intrathecal space, deformation of the nervous roots, and spinal cord constriction. ${ }^{18,21,22,23}$ Concerned with the many AA cases reported by Australian physicians, The Medical Defence Union of New South Wales, Australia, released a warning recommending that corticosteroids should no longer be used in the epidural space. ${ }^{12,24}$ Ten years later, the use of corticoids in the epidural space was recognized as safe in a review supported by The Australian Pain Society, although the authors do not "recommend" its use. ${ }^{25}$ There is a need to find new and safer agents, as an optional to the methylprednisolone, to be used in the epidural space for treating lumbosciatic pain ${ }^{26}$. Betamethasone would be a good option since it is a hydrophilic agent with no clinical complications reported from its use in the epidural space. Latham et al. ${ }^{27}$ administered different doses of betamethasone in the intrathecal space of sheeps. They could only observe nervous tissue injuries when doses above those clinically recommended were injected. ${ }^{27}$ In dogs, an animal model used to study some agents toxicity, there are no reports of neurological harm from betamethasone. ${ }^{20}$ The objective of this study is to determine the effects of two different betamethasone doses injected in the canine intrathecal space.

\section{Methods}

After approval by The Animal Research Ethics Committee of this University, and following the Animal Experimentation Ethics, 21 adult dogs of both genders, weighing between eight and $17 \mathrm{~kg}$ and spinal lengths between 60 and $70 \mathrm{~cm}$, were enrolled in the study. They were randomly located into 3 experimental groups differentiated by the solution to be spinally administered: G1 - saline isotonic solution (1ml); G2 - betamethasone $1.75 \mathrm{mg}$ (1ml); G3 - betamethasone 3mg (1ml). Following a 12 hour fasting period with free access to water, the dogs were anesthetized with intravenous fentanyl $0.005 \mathrm{mg} \cdot \mathrm{kg}^{-1}$ and etomidate $2 \mathrm{mg} \cdot \mathrm{kg}^{-1}$. They were placed on a Claude Bernard's trough and the distance between occipital protuberance and lumbosacral space was measured to obtain the spinal length. The skin and the hair at the puncture site were cleaned with soap and water. Then an area of approximately $10 \mathrm{~cm}$ around the L6-L7 interspace was shaved, washed with sterile saline solution, and disinfected with $2 \%$ clorexidine solution. Sterilized drapes were placed around the disinfected area. To perform the spinal puncture, the two tuberosities of the iliac bone and of the spinal process of the last lumbar vertebra were identified. The lumbosacral space was located immediately below. By sliding the finger in the cephalic direction, the next inter-vertebra space was L6-L7; this was the site where the puncture was performed using a disposable 25G Quincke needle which was inserted through median access at approximately $45^{\circ}$. After crossing the arachnoids membrane, the needle mandrel was removed to obtain free CSF leakage - proof of correct needle placement. The blinded solution was then injected. After puncture procedure, and recovery from intravenous anesthesia, the dogs were clinically observed by evaluating anal sphincter relaxation, presence of hind limb paralysis and testing for painful sensitivity in different dermatomes, such as the hind and front interdigital membrane, the tail, the cervical, the thoracic, the lumbar and the sacral dermatomes. A mousetooth forceps was used for sensitivity evaluation. The dogs were then observed for a 21 days period evaluating: anal sphincter relaxation, hind limb movement, ability to move the tail, and changes in sensitivity to pain. After this observational period, animals were given intravenous anesthesia and then sacrificed by electrocution. The lumbar and sacral portions of the spinal cord were removed in less than three minutes and immediately fixed in $10 \%$ formalin solution. Nerve tissue and meninges fragments were ressected at $1 \mathrm{~cm}$ intervals, beginning approximately $5 \mathrm{~cm}$ above puncture site to the end of the cauda equine. Sections were dyed with the hematoxilin-eosin stain method. Blinded evaluation was performed by the pathologist. Analysis of variance (ANOVA) was used to evaluate group homogeneity in terms of weight and spinal length; $\mathrm{p}<0.05$ was considered significant. 


\section{Results}

There were no significant differences in the animals weight $(\mathrm{F}=1.1 ; \mathrm{p}=0.35)$ and spinal length $(\mathrm{F}=0.31 ; \mathrm{p}=0.73)$ (Table 1) between the studied groups. None of the animals showed any kind of neurological changes (sensitivity, mobility, or sphincter function). Although no histological changes were observed by light microscopy in the animals from G1 (Figure 1), two animals in G2, and two animals in G3 showed meningeal and nerve tissue lesions (Tables 2 and 3) - three with fibrous thickening of the meningeal layer (Figure 2) and two with inflammatory cells (Figure 3). Nerve tissue necrosis was seen in one G2 animal (Figure 3).

TABLE 1 - Animal weights and spinal lengths. Results are medians and SD

\begin{tabular}{lccc}
\hline & Saline solution - (G1) & Betamethasone 1.75 mg - (G2) & Betamethasone 3.5 mg - (G3) \\
\hline Weight $(\mathrm{kg})$ & $9.7 \pm 2.6$ & $12 \pm 2$ & $11 . \pm 3.33$ \\
Spinal length $(\mathrm{cm})$ & $59.8 \pm 4.9$ & $62 \pm 5.6$ & $61.6 \pm 6.1$ \\
\hline
\end{tabular}

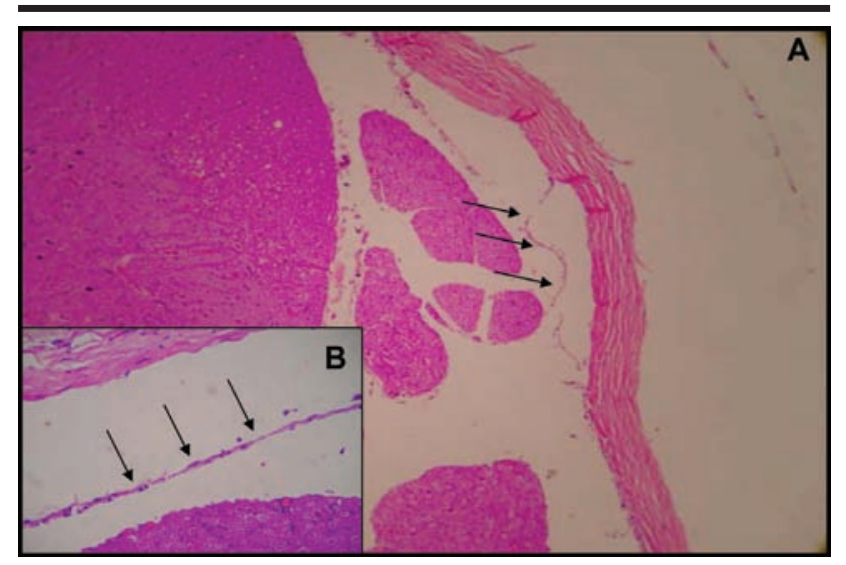

FIGURE 1 - Group 1 (saline solution). Segment of nerve and lumbar nervous tissues, meninges and arachnoids (arrows) showing no abnormalities (H\&E 10X - A; H\&E 40X - B)

TABLE 2 - Clinical and histological findings from the meninges and spinal cord (light microscopy)

\begin{tabular}{cccccc}
\hline & \multicolumn{2}{c}{ Clinical alterations } & & \multicolumn{2}{c}{ Histological alterations } \\
\cline { 2 - 3 } \cline { 5 - 6 } Groups & Yes & No & & Yes & No \\
\hline 1 & 0 & 7 & & 0 & 7 \\
2 & 0 & 7 & & 2 & 5 \\
3 & 0 & 7 & & 2 & 5 \\
\hline
\end{tabular}

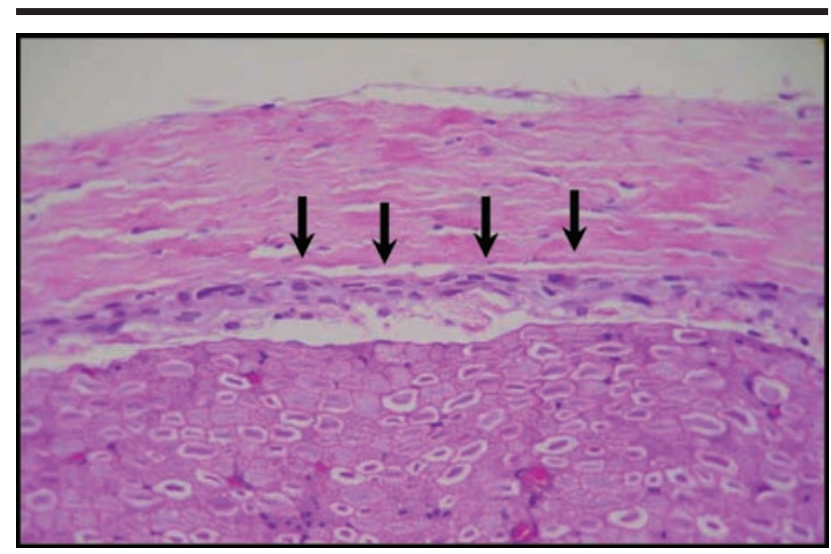

FIGURE 2 - Group 3. Segment of nerve and lumbar nervous tissues, meninges and thickness of the arachnoids (arrows). (H\&E 40X)
TABLE 3 - Histological findings in dogs from Groups 2 and 3

\begin{tabular}{lcc}
\hline & Group 2 & Group 3 \\
\cline { 2 - 3 } $\begin{array}{l}\text { Normal nervous tissue } \\
\text { thickness of meningeal layer }\end{array}$ & 1 & 2 \\
\hline $\begin{array}{l}\text { Inflammatory infiltration } \\
\text { of meningeal and nervous tissue }\end{array}$ & 1 & 0 \\
\hline Necrosis of nervous tissue & 1 & 0 \\
\hline & & \\
\hline
\end{tabular}

FIGURE 3 - Group 2. Inflammatory infiltration with neutrophils, lymphocytes, and mast cells inside the meningeal layer. Hemorragic focus and inflammatory reaction inside the nervous tissue with necrosis areas (arrow). H\&E 40X

\section{Discussion}

The dog was the chosen animal for this research since some toxicity studies have been successfully performed in this animal. These studies closely reproduce what happens in human beings. The anatomy of the dog permits easy performance of spinal block, with a low risk of puncture accidents. Methyprednisolone is currently one of the most common corticoids used for treating lumbosciatic pain by spinal route, despite relates of occurrence of AA, probably due to the presence of polyethylene glycol in its formulation. ${ }^{10,11,12,13,28,29,30,31}$ Betamethasone is an alternative to methylprednisolone since there are no reports of neural toxicity in humans and because it is a potent 
corticoid without mineralcorticoidal effects. It is about five times as potency as methylprednisolone, which is why the doses used were within those recommended for therapeutic proposals, i.e. 0.22 mg.kg-1. No clinical changes were observed during the experimental period, although tissue lesions were present. Joseph and Denson ${ }^{32}$ performed a study in monkeys, using different quantities of detergents injected into the intrathecal space. Two animals had severe histological changes, but only one of them had clinical symptoms of the disease. ${ }^{32}$ Similar results were found by different researchers using different animal models, where clinical findings did not relate to the degree of histological changes..$^{20,33,34}$ As AA develops very slowly, the neurological symptoms may be present only after a long period of evolution, reason perhaps the dogs in this study did not present any clinical findings during the experimental period of 21 days. The puncture technique was not responsible for the lesions observed in the G2 and G3 animals, since G1 animals presented no abnormalities at histological exam. Four animals from the two betamethasone groups presented histological changes. Betamethasone is a depo-corticoid with a long half-life. This means that it could have a long contact period with the nerve tissue and it allows a good distribution on the spinal cord surface. The densities of betamethasone injected solutions were 1007 and 1009 (G2 and G3 respectively). CRF has a density of 1003-1009. As density correlates with baricity it is possible to conclude that the injected solutions are isobaric, which may help their cephalic distribution. ${ }^{35}$ The necrosis in the G2 animal extended from the meningeal to peripheral spinal nervous tissue, location where the contact of the injected solution happens in a closer manner. The histological changes seem in the other animals are likely to be more important in the meningeal layer, displaying thickness with associated inflammatory process. This may indicate AA, a disease with the characteristics of an inflammatory process and posterior thickness of the arachnoids layer. ${ }^{36}$ There are many causes of AA, including radiological contrasts, bacterial and viral infections, detergents, and corticoids. Goldstein et al. ${ }^{37}$, in 1970, performed a clinical study with intrathecal methylprednisolone in 38 patients. Only one of them presented clinical AA. Since this study, the risk of methylprednisolone spinal administration has become a concern to physicians. ${ }^{38}$ One special concern is the addition of the polyethylene glycol in the commercially available methylprednisolone solutions, in the betamethasone solutions and in many others corticosteroids. It is added to the corticoid solutions to increase its solubility properties and it may be responsible for the reports of AA associated with methylprednisolone use. ${ }^{10,}$ 11, 12, 13, 29, 30, 31, 39 Selby $^{40}$, observed immediate desmielinization process when polyethylene glycol was injected in rat and rabbit peripheral nerves, optical nerve, spinal cord, and nerve root. ${ }^{40}$ Latham et al. ${ }^{27}$, only observed AA in sheep when betamethasone doses much higher than those recommended in clinical use were injected. Benzoic alcohol is another compound found in the commercial betamethasone solution used in this study. It is a preservative with anti-microbial properties, and known neurotoxicity. ${ }^{41}$ The exposition of paw nerve of rats to solutions containing polyethylene glycol and benzoic alcohol, for periods longer than one hour, resulted in permanent lesions and degeneration. ${ }^{42}$ But, at the concentrationstheyarefoundinthecommercialpreparations, they are not likely to cause nerve toxicity. ${ }^{41,43}$ However, the betamethasone doses injected in this study showed an ability to cause histological changes in the meninges and spinal cords of some dogs enrolled in this research.

\section{Conclusion}

The betamethasone solution injected in the intrathecal space, in this experimental model, determined histological changes in the meninges and spinal cord of dogs.

\section{References}

1. Saal JS, Franson RC, Dobrow R, Saal JA, White AH, Goldthwaite N. High levels of inflammatory phospholipase A2 activity in lumbar disc herniations. Spine. 1990;15(7):674-8.

2. Winnie AP, Hartman JT, Meyers HL, Jr., Ramamurthy S, Barangan V. Pain clinic. II. Intradural and extradural corticosteroids for sciatica. Anesth Analg. 1972;51(6):990-1003.

3. Hickey RF. Outpatient epidural steroid injections for low back pain and lumbosacral radiculopathy. $\mathrm{N}$ Z Med J. 1987;100:594-6.

4. Ridley MG, Kingsley GH, Gibson T, Grahame R. Outpatient lumbar epidural corticosteroid injection in the management of sciatica. Br J Rheumatol. 1988;27(4):295-9.

5. Abram SE. Perceived dangers from intraspinal steroid injections. Arch Neurol. 1989;46(7):719-21.

6. Raj PP. Epidural steroid injections. Pain Digest. 1990;9:235-40.

7. Bogduk N. Current guidelines in the use of epidural steroids: reports from Australia, Belgium, Norway, the United Kingdom, and the USA. Pain Digest. 1999;9:226-34.

8. Hooten WM, Mizerak A, Carns PE, Huntoon MA. Discitis after lumbar epidural corticoid injection: a case report and analysis of the case report literature. Pain Med. 2006;7(1):46-51.

9 Nelson DA, Landau WM. Intraspinal steroids: history, efficacy, accidentality, and controversy with review of United States food and drug administration reports. J Neurol Neurosurg Psychiatr. 2001;70:433-43.

10.Sehgal AD, Tweed DC, Gardner WJ, Foote MK. Laboratory studies after intrathecal corticosteroids: determination of corticosteroids in plasma and cerebrospinal fluid. Arch Neurol. 1963;9:64-8.

11.Brown FW. Management of diskogenic pain using epidural and intrathecal steroids. Clin Orthop. 1977:72-8.

12.Corrigan AB, Carr G, Tugwell S. Intraspinal corticosteroid injections. Med J Aust. 1982;1(5):224-5.

13.Bogduk N, Cherry D. Epidural corticosteroid agents for sciatica. Med J Aust. 1985;143(9):402-6.

14.National Health and Medical Research Council. Epidural use of steroids in the Management of Back Pain. Canberra: Commonwealth of Australia, National Health and Medical Research Council; 1994.

15.Knight CL, Burnell JC. Systemic side-effects of extradural steroids. J Neurosurg. 1978;48:1023-5.

16.Burn JM, Langdon L. Duration of action of epidural methyl prednisolone. A study in patients with the lumbosciatic syn- 
drome. Am J Phys Med. 1974;53(1):29-34.

17.Kay J, Raff H. Epidural triamcinolone causes prolonged and severe depression of the pituitary-adrenal axis. Anesthesiology. 1991;75:A694.

18.Kane RE. Neurologic deficits following epidural or spinal anesthesia. Anesth Analg. 1981;60(3):150-61.

19.Wedel DJ. Neurologic complications of central neural blockade. ASA Refresher Course Anesthesiol. 1993;21:27-39.

20.Ganem EM, Vianna PT, Marques M, Castiglia YM, Vane LA. Neurotoxicity of subarachnoid hyperbaric bupivacaine in dogs. Reg Anesth. 1996;21(3):234-8.

21.Woods WW, Franklin RG. Progressive adhesive arachnoiditis following spinal anesthesia. Calif Med. 1951;75(3):196-8.

22.Greene NM. Neurological sequelae of spinal anesthesia. Anesthesiology. 1961;22:682-98.

23.Jaradeh S. Cauda equina syndrome: a neurologist's perspective. Reg Anesth. 1993;18(6 suppl):473-80.

24.Gibb D. Spinal injection of corticosteroids. Med J Aust. 1981;2(6):302-3.

25.Gronow DW, Mendelson G. Epidural injection of depot corticosteroids: australian pain society limited. Med J Aust. 1992;157(6):417-20.

26.Aldrete JA. Epidural injections of indomethacin for postlaminectomy syndrome: a preliminary report. Anesth Analg. 2003;96(2):463-8.

27.Latham JM, Fraser RD, Moore RJ, Blumbergs PC, Bogduk $\mathrm{N}$. The pathologic effects of intrathecal betamethasone. Spine. 1997;22(14):1558-62.

28.Nelson DA, Vates TS, Jr., Thomas RB, Jr. Complications from intrathecal steroid therapy in patients wsith multiple sclerosis. Acta Neurol Scand. 1973;49(2):176-88.

29.Benzon HT, Gissen AJ, Strichartz GR, Avram MJ, Covino BG. The effect of polyethylene glycol on mammalian nerve impulses. Anesth Analg. 1987;66:553-9.

30.Nelson DA. Dangers from methylprednisolone acetate therapy by intraspinal injection. Arch Neurol. 1988;45(7):804-6.
31.McLain R. Point of view: the pathologic effects of intrathecal betamethasone. Spine. 1997;22(14):1562.

32.Joseph SI, Denson JS. Spinal anesthesia, arachnoiditis, and paraplegia. J Am Med Assoc. 1958;168(10):1330-3.

33.Rosen MA, Baysinger CL, Shnider SM, Dailey PA, Norton M, Curtis JD, Collins M, Davis RL. Evaluation of neurotoxicity after subarachnoid injection of large volumes of local anesthetic solutions. Anesth Analg. 1983;62(9):802-8.

34.Ready LB, Plumer MH, Haschke RH, Austin E, Sumi SM. Neurotoxicity of intrathecal local anesthetics in rabbits. Anesthesiology. 1985;63(4):364-70.

35.Horlocker TT, Wedel DJ. Density, specific gravity, and baricity of spinal anesthetic solutions at body temperature. Anesth Analg. 1993;76(5):1015-8.

36.Rice I, Wee MYK, Thomson K. Obstetric epidurals and chronic adhesive arachnoiditis. Br J Anaesth. 2004;92(1):109-20.

37.Goldstein NP, McGuckin WF, McKenzie BF, Mattox VR. Experimental intrathecal administration of methylprednisolone acetate in multiple sclerosis. Trans Am Neurol Assoc. 1970;95:243-4.

38.Nelson DA. Intraspinal therapy using methylprednisolone acetate: twenty-three years of clinical controversy. Spine. 1993;18(2):278-86.

39.Nelson DA, Vates TS, Jr., Thomas RB, Jr. Complications from intrathecal steroid therapy in patients wsith multiple sclerosis. Acta Neurol Scand. 1973;49(2):176-88.

40.Selby R. To the editor. Neurosurgery. 1983;12:591.

41 MacPherson RD. Pharmaceutics for the anaesthetist. Anaesthesia. 2001;56:965-79.

42.Johansson A, Hao J, Sjolund B. Local corticosteroid application blocks transmission in normal nociceptive C-fibres. Acta Anaesthesiol Scand. 1990;34(5):335-8.

43.Abram SE. Need for precise diagnosis prior to epidural steroids: clinical concepts and commentary. Anesthesiology. 2000;93(2):566-7.

\section{Correspondence:}

Guilherme Antonio Moreira de Barros

Departamento de Anestesiologia,

Faculdade de Medicina de Botucatu, UNESP

Distrito Rubião Jr, s/n

18618-970 Botucatu - SP Brazil

Fax: (55 14)3815-9015

barros@fmb.unesp.br
Conflict of interest: none

Financial source: CAPES

Received: March 13, 2007

Review: May 18, 2007

Accepted: June 15, 2007

\section{How to cite this article}

Barros GAM, Marques MEA, Ganem EM. The effects of intrathecal administration of betamethasone over the dogs' spinal cord and meninges. Acta Cir Bras. [serial on the Internet]2007 Sept-Oct;22(5).Available from URL: $\underline{\text { http://www.scielo.br/acb }}$ 